\author{
Lucyna Kopciewicz. \\ Uniwersytet Gdański \\ pedlk@ug.edu.pl
}

\title{
Jak nauczyciele wykorzystują technologie komunikacyjne w pracy szkoły? Cyfrowe projektowanie dydaktyczne i teoria Pierra Rabardela w badaniach dydaktycznego potencjału urządzeń mobilnych
}

\begin{abstract}
Summary
How do teachers use communication technologies at school?

Digital didactic design and the theory of Pierre Rabardel as the research framework for analyzing the educational potential of mobile devices

This article presents and discusses results of empirical research conducted during 2 school semesters at primary school in Poland. This study, using a qualitative approach, aims at the tracing of the process of the implementation of tablets and robots to the didactic design at primary school, the tracing of progressive changes in the area of teaching and learning practices. The results show the dominating technological schemes developed by teachers: a) technologies function in a "closed" form - they are used for displaying ready content and structures to be identified or memorised and b) technologies are used by teacher as "open structures" constituting a collection of various tools subordinated to the intentions of the child as an active creator.
\end{abstract}

Słowa kluczowe: wczesna edukacja, technologie mobilne, roboty, projektowanie dydaktyczne, narzędzia, mediacja

Keywords: early education, mobile technology, robots, didactic design, tools, mediation

W ostatnich latach w obszarze dydaktyki intensywnie badana jest kwestia włączania technologii mobilnych w pracę szkoły ${ }^{1}$. Niemniej jednak brakuje badań ukazujących proces tejże integracji przez pryzmat kształtowania się nowych sposobności i dróg uczenia się (Cerratto-Pargman i in. 2017). Celem niniejszego artykułu jest wgląd w wyłaniające się praktyki uczenia się i nauczania w dwóch klasach pierwszych w jednej pomorskich szkół podstawowych, obserwowanych w dłuższej perspektywie czasowej dwóch semestrów na-

\footnotetext{
1 Tekst powstał $\mathrm{w}$ ramach projektu badawczego finansowanego przez Narodowe Centrum Nauki 2015/19/B/HS6/02218: Uczenie się wspomagane technologiami mobilnymi w szkołach pomorskich. Krytyczne pytania o rozwój „kompetencji XXI wieku” oraz genderową inkluzję w szkolnych modelach BYOD/BYOT oraz OPD.
} 
uki. Jest to badanie w małej skali, dokumentujące sposoby włączania nowych narzędzi w procesy projektowania dydaktycznego.

\section{Rama teoretyczna}

W celu zwiększenia czytelności konstrukcji badania i interpretacji jego wyników zdecydowałam o podziale artykułu na dwie części. W pierwszej zostaną krótko omówione dwie teorie: cyfrowego projektowania dydaktycznego i model SAMR oraz wyniki badań zinterpretowane z uwzględnieniem obu podejść teoretycznych. W drugiej części przedstawię teorię instrumentalnej genezy Pierra Rabardela i wyniki badań, w których interpretacji odwołałam się do tej teorii.

\section{Cyfrowe projektowanie dydaktyczne}

Analizowanie procesów integrowania technologii w klasach szkolnych ma długą tradycję badawczą i wypracowany zestaw podejść badawczych. Na użytek niniejszych badań przyjęta została rama teoretyczna zdefiniowana na gruncie cyfrowego projektowania dydaktycznego (Jahnke i in. 2017). Nauczyciel jest tu traktowany jako strategiczny projektant, który otwiera nowe przestrzenie uczenia się przez rozwijanie infrastruktur dla interakcji między uczestnikami (Dylak 2013: 170). W perspektywie cyfrowego projektowania dydaktycznego badaniu podlegają zazwyczaj trzy komponenty: nauczanie, uczenie się i integracja technologii (Jahnke, Kumar 2014). W badaniach własnych przyjęłam większy stopień ich uszczegółowienia, biorąc pod uwagę następujące elementy:

- typ przyjętych celów kształcenia,

- typ planowanych działań uczenia się,

- wykorzystanie zasobów dydaktycznych, w tym technologii,

- zakładaną rolę ucznia,

- zakładaną rolę nauczyciela

- ocenianie i informacje zwrotne,

- sposób włączania technologii w aktywność lekcyjną.

\section{Model SAMR}

Kolejnym źródłem teoretycznym jest model SAMR, który pozwala opisać zróżnicowane sposoby włączania technologii w procesy nauczania i uczenia się w klasie szkolnej. Model ten jest pomocny w zrozumieniu miejsca, roli i znaczenia (sensu) technologii (Puentedura 2014). Autor zidentyfikował kilka poziomów integracji technologii z procesami kształcenia, z których daje się „wyczytać” to, w jaki sposób nauczyciele się nimi posługują:

- substytucja: technologie są wykorzystywane do wykonywania tych samych zadań, które można wykonać bez ich udziału (zastępują tradycyjne), 
- rozszerzenie (augmentation): na tym poziomie technologia wykorzystana jest jako skuteczne narzędzie rozwiązywania podstawowych problemów, oferując ulepszenie wykonania zadań oraz natychmiastową informację zwrotną o poziomie jego wykonania,

- modyfikacja: to pierwszy poziom, w którym odchodzi się od tradycyjnego modelu nauczania, a technologia zaczyna odgrywać znaczącą rolę dydaktyczną; jest ona niezbędnym narzędziem do wykonania zadania,

- redefinicja: nowe narzędzia są niezbędne do wykonania złożonych zadań, choć kluczowe są umiejętności i postawy uczniów: innowacyjność, współpraca, skuteczna komunikacja pomiędzy członkami zespołu.

\section{Informacje o projekcie badawczym}

Prezentowane wyniki badań są częścią szerszego projektu dotyczącego roli technologii mobilnych i robotów w projektowaniu edukacyjnym w Polsce. W tej części artykułu odniosę się do węższego ich zakresu. W celu poszerzenia wiedzy na temat tego, jakie praktyki ujawniają się w klasach szkolnych wyposażonych w tablety i roboty edukacyjne, przeprowadzone zostały badania empiryczne w jednej z pomorskich szkół podstawowych w małym mieście. W badaniach uczestniczyło 34 pierwszoklasistów z dwóch zespołów klasowych oraz dwie nauczycielki wczesnej edukacji (o krótkim stażu pracy - 3 i 4 lata). Zebrany materiał badawczy stanowi 30 obserwacji w klasie, uzupełnionych notatkami terenowymi, fotografiami z przebiegu lekcji w ciągu dwóch semestrów nauki (po 15 obserwacji w każdej klasie). Obserwowane były te same zespoły uczniowskie i te same nauczycielki, co pozwoliło zachować ciągłość i udokumentować ewentualne zmiany w sposobach edukacyjnego użycia tabletów i robotów w istniejących ramach i dłuższej perspektywie czasowej.

\section{Operacjonalizacja przyjętych modeli teoretycznych - modelu projektowania dydaktycznego i modelu SAMR dla analiz wyłaniających się praktyk nauczania i uczenia się w klasie szkolnej}

Przyjmując za punkt wyjścia teorię cyfrowego projektowania dydaktycznego oraz model SAMR, opracowano narzędzie do analizy obserwowanych lekcji. Schemat kodowania, który przedstawiono $\mathrm{w}$ tabeli 1 był kilkukrotnie dyskutowany $\mathrm{z}$ większym zespołem badawczym. W schemacie tym pojawiły się nazwy głównych analizowanych kategorii (A-G). Następnie, wykorzystując wiedzę na temat możliwych etapów integracji technologii w klasie szkolnej, przypisano wartości (na skali od 1 do 5) oznaczające identyfikowalne i rozłączne zakresy działań nauczycieli, uczniów oraz sposobów wykorzystania technologii na lekcjach. Wartości najniższe (1 i 2) odpowiadają transmisyjnej logice szkoły, z koncentracją na przekazie „,zamkniętej” wiedzy, podręczniku i czynnościach zapamiętywania (Klus-Stańska 2011, Klus-Stańska 2012). W tych kontekstach technologia 
jest wyraźnie wtłoczona w porządek orientacji transmisyjnej. Wartość 3 odnosi się do prób przełamania transmisyjnej logiki szkoły w analizowanych zakresach działań, choć jednocześnie nacechowana jest dużą nauczycielską presją i wzmożoną kontrolą (wyrażoną w częstych komunikatach nauczycielskich w postaci „musisz” i „nie wolno”). Wartości 4 i 5 odnoszą się do konstruowania sytuacji uczenia się poza ramą transmisyjnego porządku. Są to próby tworzenia sytuacji uczenia się angażującego poznawczą ciekawość ucznia, niezależne myślenie, umiejętności analizy i współdziałania w zespole. Są to zatem próby oddolnego konstruowania alternatywnego modelu progresywnego uczenia się, w którym znaczącą rolę pełni technologia.

Tabela 1. Schemat kodowania

\begin{tabular}{|c|c|}
\hline Kategoria & Opis przyjętego schematu kodowania \\
\hline $\begin{array}{l}\text { A. Typ przyjętych } \\
\text { celów kształcenia }\end{array}$ & $\begin{array}{l}\text { 1. niejasne, realizacja tematu zajęć } \\
\text { 2. dostarczenie wiedzy, utrwalanie wiedzy/ umiejętności } \\
\text { 3. poszukiwanie informacji/ rozwiązanie problemu w ramach narzuconych } \\
\text { przez nauczyciela } \\
\text { 4. poszukiwanie informacji/ rozwiązanie problemu przez przetwarzanie } \\
\text { rozwiązań zaproponowanych przez nauczyciela } \\
\text { 5. samodzielne wytwarzanie wiedzy/ rozwiązanie problemu w nowej formie }\end{array}$ \\
\hline $\begin{array}{l}\text { B. Typ } \\
\text { realizowanych } \\
\text { działań uczenia } \\
\text { się }\end{array}$ & $\begin{array}{l}\text { 1. oglądanie materiałów poglądowych (prezentacji przygotowanej przez } \\
\text { nauczyciela) } \\
\text { 2. indywidualne/ grupowe ćwiczenie, utrwalanie umiejętności } \\
\text { 3. aktywność indywidualna/ grupowa polegająca na stosowaniu rozwiązań } \\
\text { pod kontrolą nauczyciela } \\
\text { 4. aktywność grupowa polegająca na przetwarzaniu wiedzy i rozwiązań } \\
\text { problemu sugerowanych przez nauczyciela } \\
\text { 5. aktywność grupowa polegająca na wytwarzaniu wiedzy/ tworzeniu } \\
\text { rozwiązań metodą prób i błędów (zachęcanie do eksperymentowania) }\end{array}$ \\
\hline $\begin{array}{l}\text { C. Wykorzystanie } \\
\text { zasobów } \\
\text { dydaktycznych }\end{array}$ & $\begin{array}{l}\text { 1. dominacja „podręcznika”, tablet/ robot wykorzystywany marginalnie } \\
\text { 2. dominacja „podręcznika”, aplikacje ściśle podporządkowane materiałowi } \\
\text { podręcznikowemu } \\
\text { 3. przełamywanie monopolu „,podręcznika” przez wielość i zróżnicowanie } \\
\text { aplikacji } \\
\text { 4. przełamywanie monopolu „podręcznika” przez aplikacje służące } \\
\text { reorganizacji wiedzy/ rozwiązaniu problemu } \\
\text { 5. wykorzystywanie aplikacji służących wytwarzaniu wiedzy/ } \\
\text { rozwiązywaniu problemów oraz równoważenie wiedzy „podręcznikowej” }\end{array}$ \\
\hline D. Rola ucznia & $\begin{array}{l}\text { 1. odbiorca gotowych treści kształcenia } \\
\text { 2. cierpliwy wykonawca - ćwiczenie i utrwalanie dostarczanej wiedzy } \\
\text { i umiejętności (zapamiętanie) } \\
\text { 3. kopista - odtwórca treści kształcenia/ zastosowań z marginesem swobody } \\
\text { 4. przetwórca wiedzy/ rozwiązań z większym marginesem swobody - } \\
\text { przekształcanie i grupowe negocjowanie rozwiązań } \\
\text { 5. badacz i negocjator - grupowe wytwarzanie wiedzy/ poszukiwanie } \\
\text { rozwiązań w uczącym się zespole }\end{array}$ \\
\hline
\end{tabular}




\begin{tabular}{|c|c|}
\hline Kategoria & Opis przyjętego schematu kodowania \\
\hline $\begin{array}{l}\text { E. Rola } \\
\text { nauczyciela }\end{array}$ & $\begin{array}{l}\text { 1. ekspert, kontroluje krótki czas aktywności z tabletem/robotem przez } \\
\text { dodatkowe procedury } \\
\text { 2. ekspert, limituje czas korzystania z tabletów/ robotów i kontroluje } \\
\text { prawidłowość użycia aplikacji, wspiera, w razie potrzeby, w zakresie } \\
\text { technicznym } \\
\text { 3. ekspert-kontroler oraz facylitator, wspiera zaangażowanie uczniów, } \\
\text { wspiera uczniów w zakresie merytorycznym i technicznym, silna kontrola } \\
\text { procesu uczenia się } \\
\text { 4. konsultant, monitoruje kolejne etapy pracy grupowej, udziela informacji } \\
\text { zwrotnych } \\
\text { 5. towarzysz, obserwator, samodzielnych poczynań uczniowskich }\end{array}$ \\
\hline $\begin{array}{l}\text { F. Ocenianie } \\
\text { i informacje } \\
\text { zwrotne }\end{array}$ & $\begin{array}{l}\text { 1. brak informacji zwrotnej, ocenianie nie występuje } \\
\text { 2. komentarz do zajęć, rodzaj ogólnego podsumowania } \\
\text { 3. ocena skierowana do jednostki lub grupy dotycząca efektu pracy } \\
\text { 4. ocena i informacja zwrotna podczas poszczególnych etapów pracy } \\
\text { indywidualnej lub grupowej oraz po zakończeniu pracy } \\
\text { 5. kryteria oceniania ogłoszone na początku zajęć, informacja zwrotna na } \\
\text { kolejnych etapach pracy, ocena po zakończeniu pracy, elementy oceny } \\
\text { doradczej }\end{array}$ \\
\hline $\begin{array}{l}\text { G. Cele nauczania } \\
\text { w związku z rolą } \\
\text { technologii }\end{array}$ & $\begin{array}{l}\text { 1. uatrakcyjnienie transmisji wiedzy } \\
\text { 2. substytucja - usprawnienie } \\
\text { 3. poszerzenie - ulepszenie } \\
\text { 4. modyfikacja - zmiana } \\
\text { 5. redefinicja - transformacja }\end{array}$ \\
\hline
\end{tabular}

Źródło: badania własne.

\section{Procedura kodowania}

Analiza przebiegła z zastosowaniem następujących czterech kroków:

- zastosowanie schematu kodowania do każdej obserwowanej lekcji,

- przypisanie wartości kodów w poszczególnych kategoriach dla obu nauczycielek,

- wyznaczenie mediany w poszczególnych kategoriach A - G (schemat kodowania bazuje na skali porządkowej, nie - nominalnej),

- umieszczenie wartości mediany w poszczególnych kategoriach na wykresie, co umożliwia ocenę obserwowanych praktyk z punktu widzenia potencjału zmiany transmisyjnej logiki szkoły; taki sposób prezentacji danych przyjmuję za Jahnke (Jahnke, Kumar 2014).

\section{Wyniki badań}

W tej części artykułu omówię wyniki badań przedstawiające wyłaniające się praktyki nauczania i uczenia się w dwóch klasach szkolnych, w których pojawiły się technologie mobilne - tablety (w modelu 1 tablet -4 uczniów) oraz roboty edukacyjne (ozoboty 
w modelu 1 robot -2 uczniów). Zbiorcza tabela zawiera mediany w poszczególnych kategoriach działań obu nauczycielek.

Tabela 2. Mediana w poszczególnych kategoriach obserwowanych działań

\begin{tabular}{|c|c|c|c|c|c|c|c|c|}
\hline \multirow{2}{*}{ Nauczycielka } & Liczba & \multicolumn{7}{|c|}{ Mediana w poszczególnych kategoriach } \\
\cline { 3 - 9 } & obserwacji & $\mathrm{A}$ & $\mathrm{B}$ & $\mathrm{C}$ & $\mathrm{D}$ & $\mathrm{E}$ & $\mathrm{F}$ & $\mathrm{G}$ \\
\hline $\mathrm{N} 1$ & 15 & 1 & 1 & 2 & 1 & 1 & 1 & 2 \\
\hline N2 & 15 & 3 & 3 & 4 & 3 & 4 & 2 & 4 \\
\hline
\end{tabular}

Źródło: badania własne.

Wyniki uzyskane przez obie nauczycielki różnią się, co wskazuje, że dostępność identycznych zestawów narzędzi cyfrowych (tabletów i robotów) nie oznacza automatycznej synchronizacji praktyk projektowania dydaktycznego. Mimo że obie nauczycielki rozpoczynały cyfrowe projektowanie w podobnym „punkcie wyjścia” - hołdując nauczaniu transmisyjnemu, jedynie pierwsza zachowała w całości porządek nauczania transmisyjnego (uzyskane wartości 1 i 2 w przyjętej skali). Druga podjęła udane próby przełamania dotychczasowych praktyk (wartości 3 i 4).

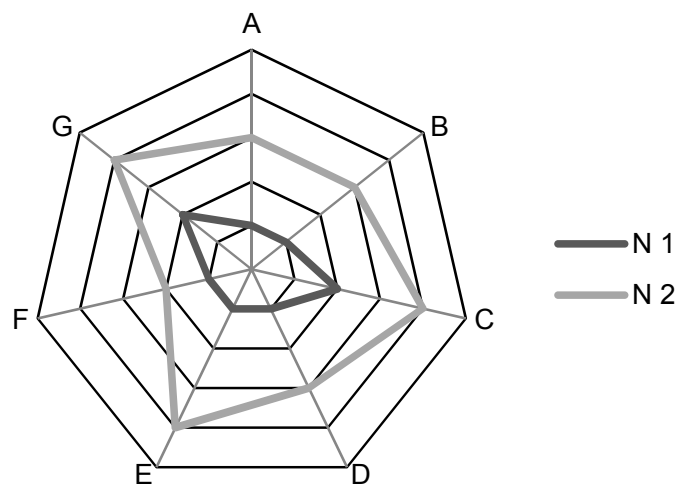

Wykres 1. Wyłaniające się praktyki nauczania i uczenia się w związku z integracją technologii w klasach pierwszych

Źródło: opracowanie własne.

\section{A. Typ przyjętych celów kształcenia}

Pierwsza nauczycielka najczęściej nie precyzowała celów kształcenia, rzadko informując o celu proponowanych ćwiczeń i nie odnosząc się do roli technologii. Chociaż i drugiej nauczycielce zdarzało się nie wspomnieć o celach zajęć i zaplanowanej roli technologii, to zdecydowanie częściej uczniowie otrzymywali takie informacje. 
B. Typ realizowanych działań uczenia się

Pierwsza nauczycielka kilka razy wykorzystała tablety, redukując je do „małych ekranów”, na których dzieci mogły obejrzeć krótkie filmy (cel ten mogła jednak osiągnąć wyświetlając ten materiał na tablicy multimedialnej). Kilka razy skorzystała z aplikacji matematycznej - puzzli. W przypadku ozobotów - ćwiczyła i utrwalała procedurę kodowania zgodnie z przyjętym przez nią schematem. Druga nauczycielka wykorzystywała tablety w bardziej zróżnicowany sposób, wykorzystując różne aplikacje: puzzle, proste konstrukcje, interaktywne książki, natomiast w przypadku ozobotów starała się stworzyć okazje do samodzielnego konstruowania nowych rozwiązań.

C. Wykorzystanie zasobów dydaktycznych

W przypadku pierwszej nauczycielki tablet pełnił marginalną rolę, czasem był wręcz zbędny. Zajęcia z ozobotami wskazały na pierwszoplanową rolę gotowych materiałów - kart pracy. Nauczycielka realizowała kolejne tematy z zaproponowanych materiałów, nie inicjując prób samodzielnego tworzenia sekwencji ruchu ozobotów. „Podręcznik” pełnił rolę dominującego zasobu dydaktycznego. W działaniach drugiej nauczycielki tablety i ozoboty były traktowane jako względnie niezależne narzędzia, używane poza kontekstem „podręcznika”. Czasami aplikacja „rozszerzała” ćwiczenia zawarte w podręcznikach, czasem podręcznik „rozszerzał” materiał zawarty w aplikacji. Nauczycielka wypracowała elastyczny model wykorzystania zasobów dydaktycznych.

\section{Rola ucznia}

W przypadku pierwszej nauczycieli uczniowie nie wykroczyli poza role odbiorców gotowych treści lub wykonawców narzuconych przez nauczycielkę rozwiązań. Ich zadaniem było wykonywanie sekwencji kodowania, proponowanych w podręczniku. Zaledwie dwa razy zdarzyło się, że nauczycielka zachęciła dzieci do samodzielnego skomponowania kodów. W przypadku zajęć drugiej nauczycielki uczniowie podejmowali także role wykonawców, ale też role twórcze - dokonując samodzielnych modyfikacji rozwiązań. Działania te zakładały współdziałanie w grupie, namysł i negocjowanie rozwiązań.

\section{E. Rola nauczyciela}

Pierwsza nauczycielka nie wykroczyła poza rolę eksperta, koncentrując się na czasie (krótkim), w którym dzieci mogły korzystać z tabletów lub robotów. Po skończonej aktywności zawsze dbała o szybkie odebranie narzędzi tak, aby nie były one w zasięgu dziecięcych rąk. Chętnie instruowała uczniów i szybko interweniowała w trakcie problemów technicznych, nie zezwalając na samodzielne próby manipulacji urządzeniami. Z kolei druga, mimo eksperckości, praktykowała facylitację, interweniując rzadko, zostawiając dzieciom otwartą przestrzeń dla wzajemnej pomocy i samodzielnych eksploracji. Czas planowanych aktywności był zróżnicowany (od krótkich do długo trwających). 


\section{F. Ocenianie i informacje zwrotne}

W obu przypadkach nauczycielki dość oszczędnie gospodarowały informacjami zwrotnymi kierowanymi do uczniów. Pierwsza w zasadzie ograniczała się do przerywania aktywności i ogłaszania końca zajęć, sporadycznie je komentując, natomiast druga nauczycielka częściej dokonywała ogólnego podsumowania, najczęściej chwaląc poszczególne grupy za dobrą pracę lub ciekawe pomysły. Rzadko można było zaobserwować ocenianie mające miejsce w trakcie wykonywanych zadań (pierwsza nauczycielka natychmiast interweniowała, gdy aktywność rozwijała się niezgodnie z planem, druga pozostawiała te kwestie dzieciom do rozwiązania - czasem nie dostrzegając perturbacji).

G. Cele nauczania w związku z rolą technologii

Sposób wykorzystania tabletów przez pierwszą nauczycielkę obejmował substytucję (film lub gry zastępowały tradycyjne materiały do ćwiczeń), natomiast ozoboty zostały przez nią wpisane w model rozszerzania (uczeń zyskiwał natychmiastową informację o poprawności swoich działań obserwując ,zachowania” robota) i sporadycznie - model modyfikacji. Technologia wykorzystywana przez pierwszą nauczycielkę służyła zatem do autokorekty wykonawstwa tak, by uczniowie sprawnie realizowali zaplanowane działania. Druga nauczycielka w swoim wykorzystaniu technologii mobilnych i robotów odwoływała się zarówno do rozszerzania, jak i do modeli modyfikacji oraz redefinicji. W jej przypadku technologia stała się warunkiem wykonania zadań, choć o ich pomyślnym przebiegu decydowały też samodzielne rozwiązania uczniowskie.

Pierwsza część analiz pozwoliła na opisanie ogólnych „,parametrów” kultury wczesnej edukacji, która ujawniła się w efektach projektowania dydaktycznego - stały się widoczne ramy, w których obie nauczycielki osadziły narzędzia cyfrowe i zdefiniowały ich rolę. Efektem tych definicji mogą być różnice doświadczeń technologiczno-edukacyjnych dwóch grup uczniowskich. Teoria instrumentalnej genezy, którą krótko omówię w drugiej części artykułu, pozwoli na dokładniejszą analizę zróżnicowanych efektów uczenia się w związku z projektowaniem dydaktycznym.

\section{Teoria instrumentalnej genezy Pierra Rabardela}

Kolejną perspektywą teoretyczną, która posłużyła do analizy i interpretacji wyników drugiego etapu badań, była teoria instrumentalnej genezy. Teorię Rabardela wykorzystuje się do analiz mikroprocesów rozgrywających się w klasie szkolnej, ale też w perspektywie makro - do globalnych analiz właściwości wprowadzanych przez narzędzia w ludzkie systemy działalności (Longchamp 2012). Punktem wyjścia tej teorii jest krytyka technocentryzmu - aktywność człowieka nie może być redukowana do funkcji wyznaczanych jej przez narzędzia (Rabardel 1995). Narzędzia zdefiniował autor jako złożoną całość, na którą składają się artefakty (ich strona materialna i techniczna) oraz podmiotowe schematy ich użycia (działania, praktyki). Zatem w ujęciu Rabardela artefakty stają się narzędziami poprzez aktywności uczącego się podmiotu, a dokładnie - przez przekształcenia artefaktów oraz transformacje 
schematów użycia. Te transformacje autor nazwał instrumentalną genezą, która obejmuje dwa procesy: zorientowany na artefakt proces instrumentalizacji (dotyczy materialnej strony instrumentu, jego nowych funkcji) i proces instrumentacji, który dotyczy podmiotu i polega na rozwijaniu nowych schematów użycia narzędzia (Rabardel, Samurcay 2001). Teoria instrumentalnej genezy pozwala naświetlić wielość relacji zachodzących między biegunami wskazanymi na schemacie 1: podmiotami, przedmiotem i narzędziem.

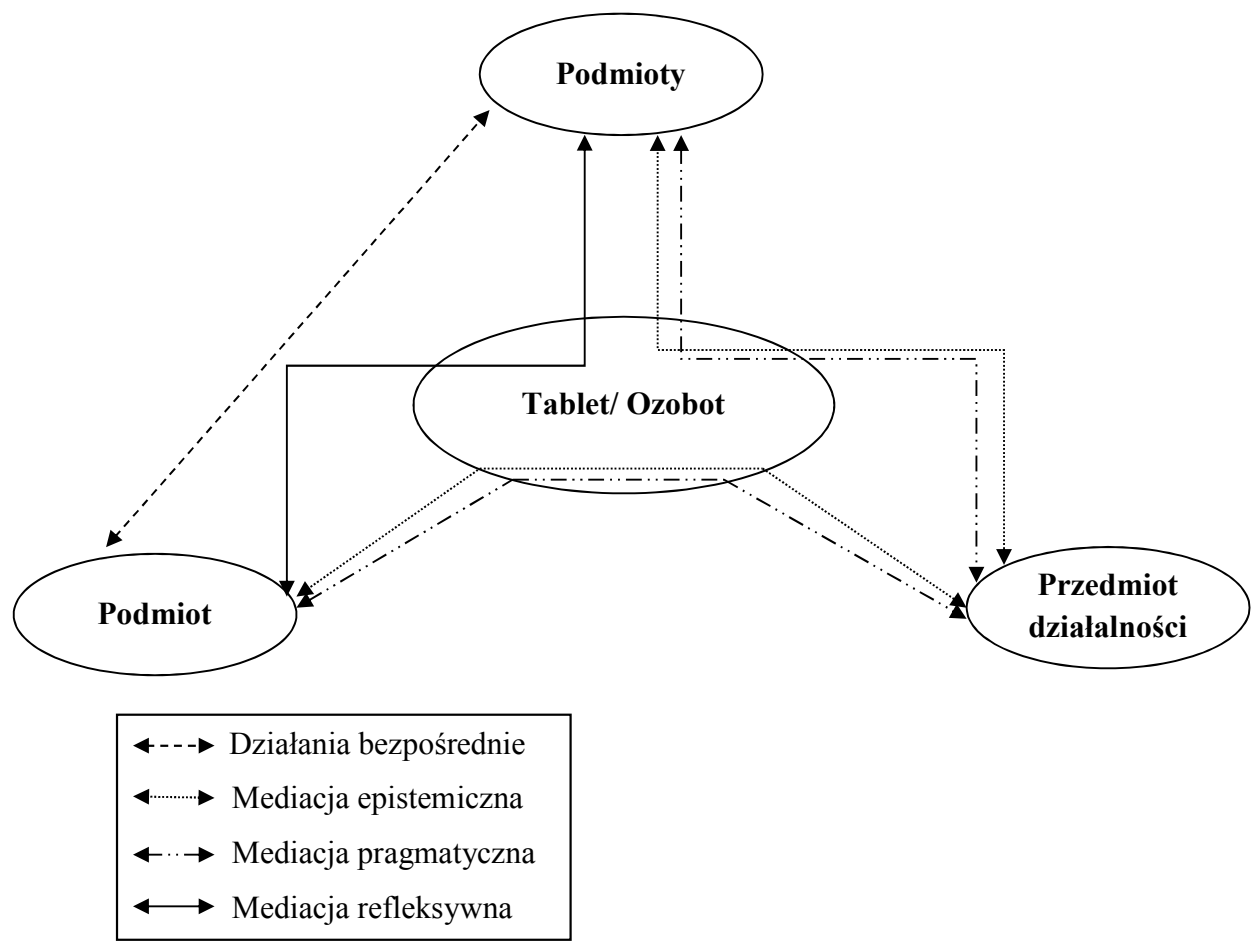

Schemat 1. Teoria instrumentalnej genezy

Źródło: na podstawie Cerratto-Pargman i in. 2017.

Warto podkreślić, że funkcją narzędzia w teorii Rabardela jest pośrednictwo między podmiotem a przedmiotem jego działalności. Zatem analizy uczenia się z wykorzystaniem narzędzi cyfrowych w szkole powinny być zogniskowane na tym, jakie schematy używania tych narzędzi są projektowane przez nauczycielki. Rabardel wskazuje kilka możliwych typów pośrednictwa zachodzącego między podmiotami i przedmiotem ich działalności:

- mediacja epistemiczna (poznawcza), która umożliwia poznanie przedmiotu i jego właściwości dzięki znajomości poszczególnych funkcji narzędzia (umiejętności jego obsługi),

- mediacja pragmatyczna - zorientowana na przekształcanie przedmiotu i osiągnięcie zamierzonych rezultatów (działania te zakładają rozumienie, w jaki sposób możliwe jest osiągnięcie rezultatu przez użycie narzędzia), 
- mediacja refleksywna - wskazuje, w jaki sposób podmiot rozumie narzędzie, np. reguluje inne działania za pośrednictwem narzędzia.

Każda z obserwowanych lekcji została „rozrysowana” i opisana przy użyciu Rabardelowskich kategorii. Każdorazowo zostały scharakteryzowane i nazwane poszczególne typy projektowanych mediacji. Następnym krokiem było porównanie tych schematów i określenie pewnej przestrzeni wynikowej - wiodących schematów użycia tabletów i robotów edukacyjnych, które zaprojektowały nauczycielki. Analiza ta pozwoliła mi na odpowiedź na pytanie, czego rzeczywiście uczą się pierwszoklasiści w kontakcie z nowymi aktorami edukacyjnymi (technologiami), a dokładniej jakie schematy użycia narzędzi cyfrowych były rozwijane podczas dwóch semestrów szkolnych zajęć.

\section{Nauczycielka 1. Zajęcia w wykorzystaniem tabletu}

Tabela 3. Kolektywne oglądanie krótkich materiałów filmowych

\begin{tabular}{|l|l|}
\hline Typ mediacji & \multicolumn{1}{|c|}{ Schemat użycia = efekt uczenia się } \\
\hline $\begin{array}{l}\text { Działania } \\
\text { bezpośrednie }\end{array}$ & $\begin{array}{l}\text { Włączenie tabletu } \\
\text { Nie wymaga współpracy }\end{array}$ \\
\hline Epistemiczna & Ustawienie parametrów urządzenia (głośno, cicho itp.) \\
\hline Pragmatyczna & Tablet nie jest narzędziem przekształcania oglądanego materiału \\
\hline Refleksywna & Narzędzie do wyświetlania gotowych treści, których się nie przekształca \\
\hline
\end{tabular}

Źródło: badania własne.

Tabela 4. Używanie aplikacji do nazywania figur itp. (dopasowanie figur)

\begin{tabular}{|l|l|}
\hline Typ mediacji & \multicolumn{1}{|c|}{ Schemat użycia = efekt uczenia się } \\
\hline $\begin{array}{l}\text { Działania } \\
\text { bezpośrednie }\end{array}$ & $\begin{array}{l}\text { Przestrzeganie kolejności użycia narzędzia („raz ty, raz ja”) - kontrola użycia } \\
\text { narzędzia }\end{array}$ \\
\hline Epistemiczna & Przesunięcie elementu palcem i umieszczenie go we właściwym miejscu \\
\hline Pragmatyczna & Rozpoznanie figury, dopasowanie adekwatnych kształtów \\
\hline Refleksywna & $\begin{array}{l}\text { Tablet to „maszynka” do uzupełniania luk i powtórzeń tych samych sekwencji } \\
\text { ruchu }\end{array}$ \\
\hline
\end{tabular}

Źródło: badania własne.

Tabela 5. Używanie robota do realizacji zaplanowanego scenariusza zajęć

\begin{tabular}{|l|l|}
\hline Typ mediacji & \multicolumn{1}{c|}{ Schemat użycia = efekt uczenia się } \\
\hline $\begin{array}{l}\text { Działania } \\
\text { bezpośrednie }\end{array}$ & $\begin{array}{l}\text { Przestrzeganie kolejności użycia ozobota („raz ty, raz ja”) - kontrola użycia } \\
\text { narzędzia }\end{array}$ \\
\hline Epistemiczna & Ozobot porusza się zgodnie z zaplanowaną sekwencją ruchów i kolorów \\
\hline Pragmatyczna & $\begin{array}{l}\text { Wprawienie w ruch ozobota możliwe jako zastosowanie procedury (dzieci } \\
\text { starają się ją zapamiętać i korygować działania kolegów) }\end{array}$ \\
\hline Refleksywna & Ozobot jako narzędzie do zapamiętania i odtworzenia sekwencji działań \\
\hline
\end{tabular}

Źródło: badania własne. 
Mimo iż w obserwowanej klasie szkolnej narzędzia cyfrowe funkcjonują w modelu „wielu użytkowników - jedno narzędzie”, co jest korzystnym układem dla grupowego uczenia się, pierwsza nauczycielka w ogóle nie projektowała tego wymiaru aktywności dzieci. Wydaje się, że dzieci poprzez bycie w grupie nauczyły się czegoś innego - kontrolowania kolegów-współużytkowników narzędzi (i pilnowania takiej samej liczby użyć narzędzia).

Jeśli chodzi o kwestię udziału dzieci w wytwarzaniu treści cyfrowych, nauczycielka planowała wyłącznie sytuacje, w których dzieci uczyły się uzupełniania luk gotowymi elementami. W przypadku kodowania zadaniem dzieci było precyzyjne wykonanie sekwencji działań zaplanowanych przez nauczycielkę (z modelem zapamiętania i odtworzenia). Zatem oba narzędzia na obserwowanych zajęciach funkcjonowały w postaci „zamkniętej", do odtwarzania gotowych struktur, które się rozpoznaje lub zapamiętuje.

W przypadku drugiej nauczycielki rozwijane schematy przybrały inny kształt.

Nauczycielka 2. Zajęcia z wykorzystaniem tabletu

Tabela 6. Używanie aplikacji do kolektywnego przygotowania książki cyfrowej

\begin{tabular}{|l|l|}
\hline Typ mediacji & \multicolumn{1}{|c|}{ Schemat użycia = efekt uczenia się } \\
\hline $\begin{array}{l}\text { Działania } \\
\text { bezpośrednie }\end{array}$ & $\begin{array}{l}\text { Przygotowanie materiałów } \\
\text { Negocjowanie kolejność pojawiania się przygotowanych materiałów }\end{array}$ \\
\hline Epistemiczna & $\begin{array}{l}\text { Dobór kolorów, zmiana kolorów i grubości linii. Utrwalenie materiałów } \\
\text { i zmontowanie ich w jedną kompozycję }\end{array}$ \\
\hline Pragmatyczna & Połączenie przygotowanych materiałów w całość składającą się z części \\
\hline Refleksywna & $\begin{array}{l}\text { Tablet jest narzędziem do wytwarzania i utrwalania własnej pracy oraz łączenia } \\
\text { jej z efektami pracy innych osób }\end{array}$ \\
\hline
\end{tabular}

Źródło: badania własne.

Tabela 7. Używanie robotów do samodzielnych eksploracji (praca w grupach)

\begin{tabular}{|l|l|}
\hline Typ mediacji & \multicolumn{1}{c|}{ Schemat użycia = efekt uczenia się } \\
\hline $\begin{array}{l}\text { Działania } \\
\text { bezpośrednie }\end{array}$ & $\begin{array}{l}\text { Komunikowanie indywidualnych zamierzeń } \\
\text { Korygowanie zamierzeń, testowanie } \\
\text { Grupa jako wyzwanie/ grupa jako wsparcie }\end{array}$ \\
\hline Epistemiczna & Odkrywanie możliwości narzędzia metodą prób i błędów \\
\hline Pragmatyczna & $\begin{array}{l}\text { Przekład planowanych sekwencji ruchu na język zapisu (kreślenie tras na } \\
\text { papierze) }\end{array}$ \\
\hline Refleksywna & $\begin{array}{l}\text { Ozobot jest narzędziem testowania i przekładu własnych pomysłów na język } \\
\text { urządzenia }\end{array}$ \\
\hline
\end{tabular}

Źródło: badania własne.

Różnicą w projektowaniu pracy dydaktycznej przez drugą nauczycielkę jest uwzględnienie kolektywności dostępnych narzędzi cyfrowych. Narzędzia były tak wykorzystywane, by zintegrować grupy wokół zadania (współpraca jest centrum podmiotowych 
aktywności, a nie sam fakt korzystania z narzędzia). Poza tym warto zauważyć, że tablety i ozoboty funkcjonowały raczej jako narzędzia „otwarte” - nauczycielka umożliwiała uczniom sprawdzenie i doświadczenie ich możliwości w związku z zadaniem (nie chodziło tu o dogmatyczne „nie wolno”, „,nie da się”). Zadania dla grup były ułożone w taki sposób, że ryzyko porażki było ograniczone, co dawało dzieciom duże pole manewrów i swobodnych eksploracji.

Poziom wykonania zadań z kodowania był zdecydowanie wyższy w drugiej grupie. Po początkowych chaotycznych próbach nieukierunkowanej aktywności (rysowania) grupy zyskały gotowość do komponowania bardziej przemyślanych, planowanych sekwencji ruchów ozobotów (z elementami korekty dokonywanymi na bieżąco). Doświadczenia zdobyte na zajęciach projektowanych przez drugą nauczycielką można zawrzeć w następującej formule: technologia to zbiór różnorodnych narzędzi podporządkowanych zamierzeniom podmiotu.

\section{Zakończenie}

Badania przedstawione $\mathrm{w}$ artykule zostały wykonane na małych próbach i z tego względu ich moc wyjaśniająca jest bardzo ograniczona. Badania te dokumentują proces wyłaniania się nowych praktyk nauczania i uczenia się w klasie szkolnej, w której pojawiły się nowe technologie. Badania ujawniły ogrom codziennej pracy konceptualnej, która towarzyszy cyfrowemu projektowaniu; ujawniły, że technologia nie działa jak czarodziejska różdżka i sama z siebie nie wyzwala żadnych efektów edukacyjnych. Współczesne technologie bywają „bezradne” wobec transmisyjnie nastawionych nauczycieli, natomiast dla niektórych mogą stać się sposobnością do rozwinięcia nowych podejść pedagogicznych i rekonstruowania własnej praktyki. Włączenie technologii w pracę dydaktyczną może również prowadzić do kształtowania się zróżnicowanych umiejętności cyfrowych i - być może - do różnic w rozumieniu technologii (i jej funkcji) przez dzieci. Warto byłoby przeprowadzić podobne badania $\mathrm{w}$ dłuższej perspektywie czasowej z udziałem większej grupy nauczycieli, by dokładniej opisać warunki, które zatrzymują nauczycielach w transmisyjnych ramach oraz te, które skłaniają ku modyfikacji własnych działań za pośrednictwem technologii.

\section{Literatura}

Cerratto Pargman T., Nouri J., Milrad M. (2017), Taking an instrumental genesis lens: New insights into collaborative mobile learning. "British Journal of Educational Technology", 1, doi:10.1111/ bjet.12585.

Dylak S. (2013), Architektura wiedzy w szkole. Warszawa, Difin.

Jahnke I., Bergström P., Mårell-Olsson E., Häll L., Kumar S. (2017), Digital Didactical Designs as research framework: iPad integration in Nordic schools. "Computers \& Education", 113.

Jahnke I., Kumar S. (2014), Digital Didactical Designs: Teachers'integration of iPads for learningcentered processes. "Journal of Digital Learning in Teacher Education", 30 (3). 
Klus-Stańska D. (2011), Dlaczego szkolna kultura dydaktyczna się nie zmienia? „Studia Pedagogiczne", 64.

Klus-Stańska D. (2012), Wiedza, która zniewala: transmisyjne tradycje w szkolnej edukacji. „Forum Oświatowe", 46 (1).

Lonchamp J. (2012), An instrumental perspective on CSCL systems. „International Journal of Computer-Supported Collaborative Learning", 7.

Puentedura R. (2014), SAMR Model, http://sites.google.com/a/msad60.org/technology-is-learning/ samr-model.

Rabardel P. (1995), Les hommes et les technologies, une approche cognitive des instruments Contemporains. Paris, Armand Colin.

Rabardel P., Samurcay R. (2001), From artifact to instrument-mediated learning. International symposium organized by the Center for Activity Theory and Developmental Work Research. Helsinki, University of Helsinki. 